\title{
Is the heating energy saving effect by lowering the temperature setpoint similar in different functional buildings?
}

\author{
Yuxin Huang ${ }^{1}$, Shurui Guo ${ }^{1}$, Zhu Cheng ${ }^{1}$, Ning Mao ${ }^{1}$ and Enshen long ${ }^{1 \mathrm{a}}$ \\ ${ }^{1}$ MOE Key Laboratory of Deep Earth Science and Engineering, College of Architecture and Environment, Sichuan University, \\ Chengdu,610065, China
}

\begin{abstract}
It is known that reducing the temperature setpoint is an effective heating energy saving measure for all kinds of buildings. This study focuses on the heating demand saving effect of the same buildings for different functional uses based on the same climatic background (Beijing) and the same reduction in the heating setpoint. Through comprehensive analysis of the absolute energy saving amount (ESA) and the relative energy saving ratio (ESR) from different time perspectives, the heating energy saving mechanism in reducing the heating temperature is discussed. Two types of completely different heating saving mechanisms were found: (1) the behavioural energy saving (BES) was dominated by those heating hours in which the outdoor air temperature or indoor integrated temperature was in the reducing range of heating setpoint, and(2) the energy saving of the temperature difference (ESTD) is dominated the rest heating hours. When the buildings were used for different functions, the annual ESA was determined by the numbers of the above two types of heating hours, and the annual heating ESR was mainly determined by the heating hours when the heating demand was large.
\end{abstract}

\section{Introduction}

Energy is an important driving force in the rapidly developing world, therefore, how to save energy better is a common concern of the whole society. According to the statistics from the China Association of Building Energy Efficiency, building energy consumption accounted for one-third of Chinese total energy consumption in 2018[1]. It is imperative to reduce the energy consumption effectively in heating seasons.

There are many factors that impact on building energy consumption. Walid[2] found that the indoor thermal comfort and the outdoor temperature were the important factors which would affect the building energy consumption. Panagiota[3] studied residential buildings in Denmark and used $19^{\circ} \mathrm{C}$ as the base heating temperature. In Burak's research[4], the heating setpoint in Canadian economically developed office buildings was even set at $23.5^{\circ} \mathrm{C}$.

In particular, the United States has higher requirements on indoor thermal comfort, and scholars mostly use the same basic setpoint in their studies on the cooling and heating energy consumption of buildings [5]. To make it more intuitive, scholars are quantifying the relative energy saving effect. According to the Sama and

\footnotetext{
a Corresponding author: longes2@163.com
}

Thomas's analysis results[6], office buildings in four American cities can all achieve a 7-15\% ESR when reducing the heating setpoint from $21^{\circ} \mathrm{C}$ to $20^{\circ} \mathrm{C}$. Tyler[7] studied office buildings when the heating setpoint for different air conditioning systems decreased from $18.2^{\circ} \mathrm{C}$ to $17.7^{\circ} \mathrm{C}$. Compared with the selected basic buildings, the general ESR was about 5\%. Furthermore, Baoping[8] found that the heat supplied between 8:00am and 7:00pm in a week saved $20 \%$ more energy than for a continuous heating supply. The building with a large heat transfer coefficient had greater energy saving potential.

In conclusion, it was difficult to horizontally compare the results because of the complicated influence factors like meteorological conditions, geometric parameters, envelope thermal characteristics and functional buildings. In view of this, this study used the same climate conditions in Beijing, the specific geometric parameters and the same thermal performance envelope to discuss the rules of the annual heating absolute ESA and relative ESR by reducing the same heating setpoint.

\section{Method}

This study investigated a three-storey building from a real project. Its total height is $10.6 \mathrm{~m}$, building area is $319.48 \mathrm{~m}^{2}$, the total area of the external envelope is $382.84 \mathrm{~m}^{2}$, the 
building volume is $990.3 \mathrm{~m}^{3}$, the shape coefficient is 0.38 and the window-wall ratio is 0.23 . The north elevation of the building is shown in Fig. 1 . The building is square, and its area and the room layout is suitable for residential as well as office use and commercial use. Therefore, it is assumed that the building can be used for different functions. The exterior wall heat transfer coefficient (HTC) is $1.2 \mathrm{~W} / \mathrm{m}^{2} \mathrm{~K}$, the outside window HTC is 2.5 $\mathrm{W} / \mathrm{m}^{2} \mathrm{~K}$, the roof $\mathrm{HTC}$ is $0.35 \mathrm{~W} / \mathrm{m}^{2} \mathrm{~K}$, and the ground HTC is $1.5 \mathrm{~W} / \mathrm{m}^{2} \mathrm{~K}$. The envelope thermal properties meet the energy saving standards in hot summer and cold winter areas of China in 2015.

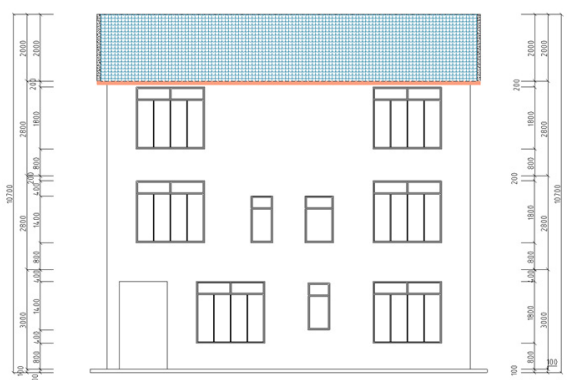

Fig.1 North elevation of the building

In this paper, according to the specifications, the internal heat source intensity for residential, office and commercial uses is determined as $9.6 \mathrm{~W} / \mathrm{m}^{2}, 20.8 \mathrm{~W} / \mathrm{m}^{2}$ and $36.6 \mathrm{~W} / \mathrm{m}^{2}$ respectively, and the air exchange rate is 0.5 times $/ \mathrm{h}$. The heating time for residential use is set for the full day, the heating time for office use is from 7:00 to 20:00, and the heating time for commercial use is from 8:00 to 21:00, regardless of holidays.

The Characteristic temperature method (CTM) was adopted for this simulation, which is a dynamic simulation method for heating load and energy consumption based on building energy consumption gene theory [10], and its reliability has been verified in many publications $[11,12]$. Taking Beijing as a representative city, the hourly meteorological parameters of Beijing were used as the basis of the study. The hours with heating load during work time were all included in the analysis.

\section{Results}

\subsection{Macroscopic energy saving effect comparison}

\subsubsection{The monthly absolute ESA}

Fig. 2 shows a comparison of the annual and monthly ESA when the heating setpoint decreases by $1^{\circ} \mathrm{C}$ for the different functional buildings. It can be seen that (1) the annual ESA for residential, office and commercial uses is $1541 \mathrm{kWh}, 432 \mathrm{kWh}$ and $211 \mathrm{kWh}$ respectively. (2) the ESA values of residential, office and commercial uses were maximum in January, as $297 \mathrm{kWh}, 121 \mathrm{kWh}$ and $64 \mathrm{kWh}$ respectively. The ESA difference between residential and commercial uses was reduced 4.6 times, which indicates that reducing the setpoint can achieve a significant energy saving effect for different functional buildings. (3) in the transition season, due to the significant difference in internal source of buildings for different usage, the difference in ESA is enlarged.

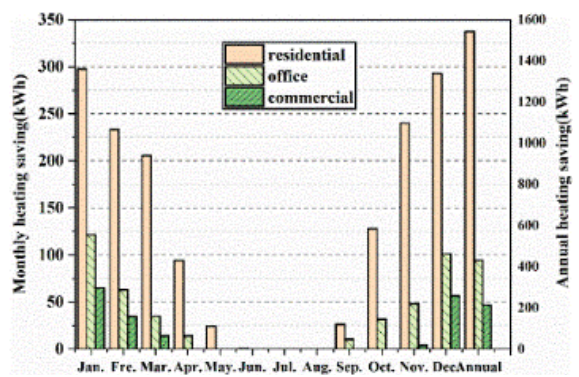

Fig.2 The monthly and annual ESA in different functional buildings

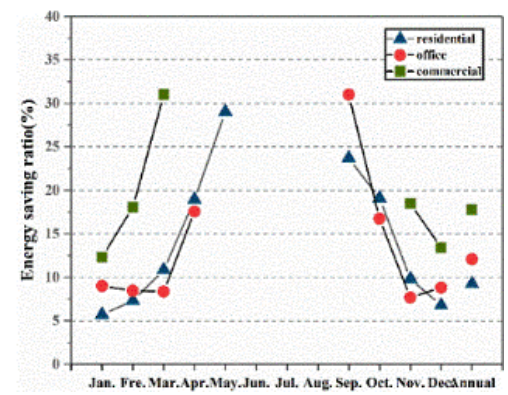

Fig.3 The monthly and annual ESR in different functional buildings

\subsubsection{The annual and monthly relative ESR}

Fig. 3 shows the monthly and annual ESR of the three buildings with different usage. Overall :(1) in terms of annual relative ESR, residential use is $9 \%$, office use is $12 \%$, commercial use is $17 \%$. (2) due to large differences in internal heat sources, the number of heating months for different functional uses is different: 9 months for residential use and only 5 months for commercial use. Therefore, the monthly ESR of buildings with different functions is significantly different. (3) as shown in the figure, in the warmer months, although the ESA is reduced with the decrease of heating consumption (as shown in Fig.4), the ESR goes higher.

\subsection{Research on the micro heating energy saving mechanism}

In order to better reveal the absolute and relative energy saving mechanism in reducing heating setpoint in different uses, buildings that adopt the continuous heating mode without internal heat source and the commercial working mode with the largest internal heat source are compared.

\subsubsection{Hourly load reduction}

As Fig. 4 shows, a point in the figure represents a moment that has heating demand. The time of heating load in the two cases was $3893 \mathrm{~h}$ and $1302 \mathrm{~h}$ respectively. As can be seen in the figure, (1)the change between hourly load reduction with the hourly heating load when the heating 
setpoint decreases by $1{ }^{\circ} \mathrm{C}$ is similar;(2) When the hourly heating load increases to a certain value, the hourly load reduction is roughly between 500 and $530 \mathrm{~W}$.

Further, it shows that:(1)the load reduction at those hours when temperature is $17^{\circ} \mathrm{C}$ is equal to the heating load when the setpoint is $18^{\circ} \mathrm{C}$. And under the combined action of outdoor solar radiation and internal effects, the indoor characteristic temperature is exactly between 17 and $18^{\circ} \mathrm{C}$, and there is no need for heating. The accumulated ESA at these hours is generated by the action of reducing the heating setpoint, so it is defined as behavioural energy saving (BES). (2) According to the building usage and the envelope structure characteristics studied in this paper, the load reduction tends to be constant at each moment, about 500 530W. The accumulated energy saving at these hours is generated by the temperature difference when the heating setpoint decreases, so it is defined as the energy saving of the temperature difference (ESTD).(3) statistics show that for the two cases, the number of hours for BES are 192 and 176, and the number of hours for ESTD are 3701 and 1126 , respectively.(4) in the case of no internal heat source, the ESTD amount is $2007 \mathrm{~kW}$, accounting for $98 \%$ of the annual heating energy saving; For commercial use, the ESTD amount is $196 \mathrm{~kW}$, accounting for $93 \%$ of the annual heating energy saving. It can be seen that the ESTD plays a major role in the energy saving effect in reducing heating setpoint.

\subsubsection{Hourly load reduction ratio}

Fig. 5 shows the change of the hourly load reduction ratio with hourly heating load. In general, (1) the variation range of the hourly heating load for commercial use is smaller than that without internal heat sources, but the hourly load reduction ratio of the two cases is consistent with the variation of heating load.(2) no matter how different the building usage and working hours are, the changes of the micro-level hourly load reduction ratio are essentially similar.(3) for those hours dominated by BES, the load reduction ratio was $100 \%$; there were 192 hours in the case of no internal heat source, and 176 hours in the case of commercial use.(4) in those hours dominated by ESTD, the scatter of the hourly load reduction ratio all formed a steep curve, and the scatter without internal heat source was up to $3701 \mathrm{~h}$, while that for commercial use was only $1126 \mathrm{~h}$. (5) the characteristics of the distribution curve of the hourly load reduction ratio further reveal the micro mechanism of the large energy demand and saving and the small energy saving ratio.

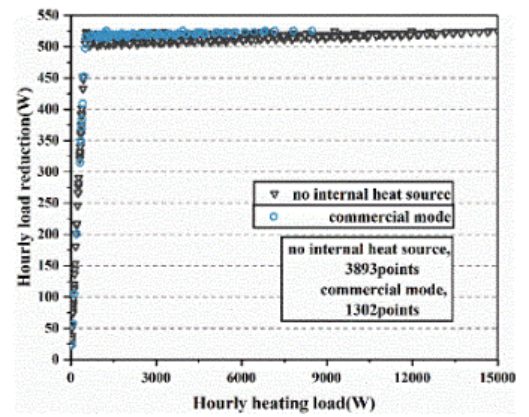

Fig.4 Varied curve of hourly load reduction with hourly heating load

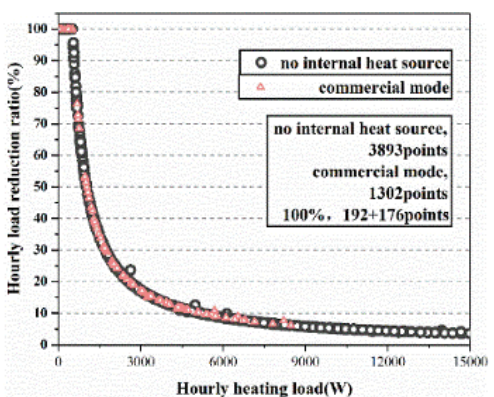

Fig.5 Change of hourly ESR with hourly heating load

\section{Discussion}

Due to the complex coupling effect of the setpoint reduction on the heating energy saving effect, it is difficult for researchers to verify the research through experimentation. Here, the representative results for office use studied in this paper are compared with similar results of Michal[13], who studied the ESR of DOE midsized office buildings when the heating setpoint decreases in several American cities. Baltimore, which has a similar climate to Beijing, was chose for comparation. The relevant building parameters, such as meteorological data, envelope structure characteristics, setting conditions, simulation methods and results are summarized in table 1.

Table 1. Comparison of different calculation parameters between this paper and reference

\begin{tabular}{|c|c|c|c|c|c|c|c|}
\hline Category & project & $\begin{array}{l}\text { this } \\
\text { paper }\end{array}$ & Michal & $\begin{array}{c}\text { Cond } \\
1\end{array}$ & Cond2 & $\begin{array}{c}\text { Cond } \\
3\end{array}$ & Cond4 \\
\hline \multirow{3}{*}{$\begin{array}{l}\text { Building } \\
\text { parameter } \\
\mathbf{S}\end{array}$} & Building area $\mathrm{m}^{2}$ & 319 & 4983 & 319 & 319 & 319 & 319 \\
\hline & Shape coefficient & 0.38 & 0.22 & 0.38 & 0.38 & 0.38 & 0.38 \\
\hline & $\begin{array}{c}\text { window-wall area } \\
\text { ratio }\end{array}$ & 0.23 & 0.33 & 0.23 & 0.23 & 0.23 & 0.23 \\
\hline \multirow{4}{*}{$\begin{array}{l}\text { Meteorolo } \\
\text { gical } \\
\text { parameter } \\
\text { s }\end{array}$} & city & Beijing & $\begin{array}{c}\text { Baltim } \\
\text { ore }\end{array}$ & Beijing & $\begin{array}{c}\text { Baltim } \\
\text { ore }\end{array}$ & Beijing & $\begin{array}{c}\text { Baltim } \\
\text { ore }\end{array}$ \\
\hline & HDD & 2705 & 2537 & 2705 & 2537 & 2537 & 2537 \\
\hline & $\begin{array}{l}\text { Annual average } \\
\text { outdoor } \\
\text { temperature }{ }^{\circ} \mathrm{C}\end{array}$ & 13.4 & 12.6 & 13.4 & 12.6 & 12.6 & 12.6 \\
\hline & $\begin{array}{c}\text { The average } \\
\text { outdoor }\end{array}$ & 6.6 & 7.3 & 6.6 & 7.3 & 7.3 & 7.3 \\
\hline
\end{tabular}




\begin{tabular}{|c|c|c|c|c|c|c|c|}
\hline & $\begin{array}{c}\text { temperature in } \\
\text { heating season }{ }^{\circ} \mathrm{C}\end{array}$ & & & & & & \\
\hline & $\begin{array}{c}\text { Total global } \\
\text { horizontal } \\
\text { radiation } \mathrm{kWh} / \mathrm{m}^{2}\end{array}$ & 1246 & 1482 & 1246 & 1482 & 1482 & 1482 \\
\hline & $\begin{array}{c}\text { Total horizontal } \\
\text { radiation in heating } \\
\text { season } \mathrm{kWh} / \mathrm{m}^{2}\end{array}$ & 564.9 & 624.4 & 564.9 & 624.4 & 624.4 & 624.4 \\
\hline \multirow{4}{*}{$\begin{array}{c}\text { Thermal } \\
\text { performa } \\
\text { nce of } \\
\text { envelope }\end{array}$} & $\begin{array}{c}\text { Exterior wall HTC } \\
\mathrm{W} / \mathrm{mK}^{2}\end{array}$ & 1.2 & 1.42 & 1.2 & 1.2 & 1.42 & 1.42 \\
\hline & $\begin{array}{l}\text { Outer window } \\
\text { HTC } \mathrm{W} / \mathrm{mK}^{2}\end{array}$ & 2.5 & 1.4 & 2.5 & 2.5 & 1.4 & 1.4 \\
\hline & Roof HTC W/mK ${ }^{2}$ & 0.35 & 0.4 & 0.35 & 0.35 & 0.4 & 0.4 \\
\hline & Floor HTC W/mK $\mathrm{m}^{2}$ & 1.5 & 0.4 & 1.5 & 1.5 & 0.4 & 0.4 \\
\hline \multirow{7}{*}{ Set cond } & SHGC & 0.65 & 0.385 & 0.65 & 0.65 & 0.65 & 0.385 \\
\hline & $\begin{array}{l}\text { Personnel density } \\
\mathrm{m}^{2} / \text { person }\end{array}$ & 12.76 & 18.58 & 12.76 & 12.76 & 12.76 & 18.58 \\
\hline & $\begin{array}{l}\text { Lighting density } \\
\mathrm{W} / \mathrm{m}^{2}\end{array}$ & 4.51 & 10.76 & 4.51 & 4.51 & 4.51 & 10.76 \\
\hline & $\begin{array}{l}\text { Device density } \\
\mathrm{W} / \mathrm{m}^{2}\end{array}$ & 8.77 & 10.76 & 8.77 & 8.77 & 8.77 & 10.76 \\
\hline & Air changes & 0.5 & 0.65 & 0.5 & 0.5 & 0.5 & 0.65 \\
\hline & Work and rest time & $\begin{array}{l}7: 00- \\
20: 00\end{array}$ & $\begin{array}{l}6: 00- \\
21: 00 \\
\end{array}$ & $\begin{array}{l}7: 00- \\
20: 00 \\
\end{array}$ & $\begin{array}{l}7: 00- \\
20: 00 \\
\end{array}$ & $\begin{array}{l}7: 00- \\
20: 00\end{array}$ & $\begin{array}{l}6: 00- \\
21: 00\end{array}$ \\
\hline & $\begin{array}{c}\text { Temperature } \\
\text { drop }{ }^{\circ} \mathrm{C} \\
\end{array}$ & $18-17$ & $21-18$ & $21-18$ & $21-18$ & $21-18$ & $21-18$ \\
\hline method & $\begin{array}{c}\text { Calculation } \\
\text { method }\end{array}$ & CTM & $\begin{array}{l}\text { Energy } \\
\text { Plus } \\
\end{array}$ & CTM & CTM & CTM & CTM \\
\hline results & $\begin{array}{c}\text { The energy-saving } \\
\text { ratio } \%\end{array}$ & 12 & 24 & 20.7 & 21.5 & 22.5 & 23.4 \\
\hline
\end{tabular}

It can be seen from the table that: (1) according to the respective research conditions, the ESR of the heating setpoint reduction by $1{ }^{\circ} \mathrm{C}$ in our paper is about $12 \%$, while the ESR of setpoint reduction by $3^{\circ} \mathrm{C}$ in reference is $24 \%$. (2) according to the reference, the setpoint is changed from 21 to $18^{\circ} \mathrm{C}$, a reduction of $3^{\circ} \mathrm{C}$ (working condition 1 ), the ESR is $20.7 \%, 3.3 \%$ lower than that of the reference, because Beijing has a lower temperature and less solar radiation than Baltimore in winter. The shape coefficient and outside window heat transfer coefficient are bigger, and leads to a greater heating demand.(3) if the weather data of Baltimore is used for simulation (working condition 2), the ESR is increased to $21.5 \%$, indicating that the ESR increases after the winter climate becomes warmer.(4) if the envelope thermal performance is also simulated according to the reference (working condition 3 ), the ESR was further increased to $22.5 \%$. If the envelope thermal performance is improved, it can reduce the heating demand and increase the ESR. (5) if the internal effects and working hours are further simulated according to the same parameters in the reference (working condition 4), the ESR was further increased to $23.4 \%$, this is closer to that in reference. (5) the building shape coefficient in our paper is larger than that in the office building in the reference (Michal et al., 2019), but the window-wall area ratio is smaller than that in the reference. The positive and negative influences of the two usage on the heating demand may weaken the influence, so the similarity between them is qualitatively credible.

Finally, it's very difficult to make a strict comparison; The simulation methods used in this paper and in the reference are CTM and EnergyPlus, respectively. The reliability of the relevant results obtained by the CTM method is proven in the above comparison.

\section{Conclusions}

This research investigated the energy-saving effect of buildings with different usage. The following conclusions are drawn:

(1) If a building has smaller internal effects, it will have greater heating demand, greater annual absolute ESA, but smaller relative ESR.

(2)The heating demand becomes 0 (BES) at those hours when the indoor characteristic temperature reaches the range under the combined action of the internal and external effects; For the rest of the hours, when there is heating demand, the reduction of the heating load is basically a constant value which depends on the envelope heat transfer coefficient, area and temperature reduction (ESTD).

(3) The absolute ESA is mainly dominated by the temperature saving mechanism. For residential use, the ESTD accounts for $98 \%$, while for commercial use, the ESTD accounts for $93 \%$. The BES mechanism plays an important role in increasing the relative ESR.

The research results of this paper can provide theoretical support for countries or regions like China that pay more attention to realizing the same ESR $(50 \%, 65 \%)$ in building energy saving standard systems. 


\section{References}

1. Zhen Yu, Wei Liu. Development status and prospect of passive ultra-low-energy buildings in China. J. Power demand side management, 2018, 20(05):1-4 (In Chinese).

2. Walid Belazi, Salah-Eddine Ouldboukhitine, Alaa Chateauneuf, Abdelhamid Bouchair, Experimental and numerical study to evaluate the effect of thermostat settings on building energetic demands during the heating and transition seasons, Applied Thermal Engineering, Volume 152, 2019, Pages 3551, ISSN 1359-4311.

3. Panagiota Gianniou, Christoph Reinhart, David Hsu, Alfred Heller, Carsten Rode, Estimation of temperature setpoints and heat transfer coefficients among residential buildings in Denmark based on smart meter data, Building and Environment, Volume 139, 2018, Pages 125-133, ISSN 0360-1323.

4. H. Burak Gunay, Weiming Shen, Guy Newsham, Araz Ashouri, Modelling and analysis of unsolicited temperature setpoint change requests in office buildings, Building and Environment, Volume 133, 2018, Pages 203-212, ISSN 0360-1323.

5. Ashrant Aryal, Burcin Becerik-Gerber, Energy consequences of Comfort-driven temperature setpoints in office buildings, Energy and Buildings, Volume 177, 2018, Pages 33-46, ISSN 0378-7788.

6. Sama Aghniaey, Thomas M. Lawrence, The impact of increased cooling setpoint temperature during demand response events on occupant thermal comfort in ltd. buildings: A review, Energy and Buildings, Volume 173, 2018, Pages 19-27, ISSN 0378-7788.

7. Tyler Hoyt, Edward Arens, Hui Zhang, Extending air temperature setpoints: Simulated energy savings and design considerations for new and retrofit buildings, Building and Environment, Volume 88, 2015, Pages 89-96, ISSN 0360-1323.

8. Baoping $\mathrm{Xu}$, Shaoxiang, Zhou Wenju $\mathrm{Hu}$, An intermittent heating strategy by predicting a warm up time for office buildings in Beijing, Energy and buildings, Volume 155, 2017, 35-42 Pages, ISSN 0378-7788.

9. GB50019-2003 "Design Specifications for Heating Ventilation and Air Conditioning". J. China construction information (special issue on heating and cooling), 2004,000 (3):19-21,25(In Chinese).

10. Enshen Long. Gene theory of building energy consumption and practice of building energy conservation. M. Beijing: science press,2009(In Chinese).

11. Yanru Li, Suo Wang, Xi Meng et al. Study on indoor temperature variation characteristics of intermittent air conditioners in different terminal start-up processes. J. Refrigeration and air conditioning (sichuan),2015,29(05):533-537(In Chinese).

12. Shurui Guo, Hanyu Yang, Yanru Li, Yin Zhang, Enshen Long, Energy saving effect and mechanism of cooling setting temperature increased by $1{ }^{\circ} \mathrm{C}$ for residential buildings in company's cities,Energy and Buildings, Volume 202, 2019, 109335, ISSN 03787788.

13. Michal Vesely, Rick Kramer, Wim Zeiler. Energy performance of personalized heating: A Numerical case study for a medium sized office building $\mathrm{o}$ company envelope qualities and climates. Journal of building Engineering. The Volume 21. 2019. Pages 113-119. ISSN 2352-7102. 